\title{
The Dutch background of Bernard Mandeville's thought: escaping the Procrustean bed of neo-Augustinianism
}

\author{
RUDI VERBURG \\ Erasmus University Rotterdam
}

\begin{abstract}
This paper argues that the neo-Augustinian outlook of the French moral tradition has been used for too long as a Procrustean bed, thereby depreciating the Dutch background of Mandeville's thought. In particular, Johan and Pieter de la Court were an important source of inspiration for Mandeville. In trying to come to terms with commercial society, the brothers developed a positive theory of interest and the passions, emphasizing the social utility of self-interest and honour in securing the health and wealth of the commonwealth. By combining elements from neo-Augustinian and Dutch commercial republican discourses, Mandeville devised a new logic for interpreting the nature and growth of commercial society, which was to inspire intense debate.
\end{abstract}

Keywords: Mandeville, commercial society, Johan and Pieter de la Court, Dutch commercial republicanism, French moral tradition

\section{INTRODUCTION}

The grimness of the debates following the publication of the Fable of the bees in 1723 is a testament to Bernard Mandeville's provocative originality. However, as Horne described it, Mandeville was "not simply an eccentric who surfaced unaccountably" (1978, 19). Among the intellectual sources from which Mandeville drew inspiration (cf., Horne 1978; Kaye 1988; Goldsmith 1985; Hundert 1994; 2003; and Cook 1999), most emphasis has been placed upon the French moral tradition and in particular to Jansenist philosophy. And sure enough, many of the themes which we find in Mandeville can be traced directly to the French intellectual tradition. Nevertheless, the neo-Augustinian outlook of the French moral tradition should not be turned into a Procrustean bed

AUTHOR's NotE: previous versions of this paper were discussed at the Mandeville Conference in Rotterdam 2014 and the ESHET Conference 2015 in Rome. Thanks for helpful comments and suggestions go to the audiences of both events, in particular to Richard van den Berg, as well as to Marianne Klerk and two anonymous referees of this journal. 
thereby depreciating the Dutch foundations of Mandeville's thought. This paper advances the argument that what is discarded from the Procrustean bed of neo-Augustinianism tells us something about the origins and originality of Mandeville's thought and that his Dutch background is a neglected part of that story.

In the seventeenth century trade and commerce increasingly came to be recognized as the fountain-head from which the well-being of the commonwealth sprang, generating the means necessary to pay for government, infrastructure, and security. Yet, trade and commerce thrive on individuals' ambitions and desires for gain. In this way, the human passions-which were previously perceived as unruly-became a necessary ingredients of public well-being. The Dutch republicanism of Johan and Pieter De la Court can be seen as an attempt to come to terms with commercial society-i.e., with its opportunities, threats, and conditions. In reappraising the role of man's passions, they emphasized the positive contribution of interest and honour in securing the health and wealth of the commonwealth. It is this positive theory of interest and the passions that formed both the foundation of Mandeville's thought as well as the French moral tradition.

The paper has the following structure: section 2 and section 3 review the French moral tradition and the views of the brothers De la Court, respectively, while section 4 compares and contrasts the logic of both discourses. Section 5 then shows how Mandeville devised a new logic based on ideas taken from both discourses; it is argued that the commercial republicanism of Johan and Pieter de la Court provided Mandeville with a springboard for navigating passage into commercial modernity. Section 6 concludes the paper.

\section{THE FRENCH MORAL TRADITION}

Following the second commercial revolution in the latter half of the fifteenth century, European society changed gradually but irrevocably. Profound changes in theology, natural science, statecraft, and economic activity increasingly challenged the established world view. As the cohesive force of religious truths broke down, a quest began for a new vision of a peaceful and decent society. By consequence, the sixteenth and seventeenth centuries were the scene of a bewildering array of ideas, views, and propositions. This quest involved a rethinking of traditional ways of self-understanding, including the moral agency of man. Traditional concepts and ideas were fitted to accommodate new 
circumstances and new economic, political, social and religious conditions. Novel languages were developed to discuss the terms and conditions of change, to articulate newly found aspirations, and to legitimize change and ideals. There is no doubt that these languages overlapped (as well as conflicted) given their common interest in theorizing about human nature and the good life in a moral community, acquiring their own perspective from discrete assumptions and challenges.

A key issue that preoccupied many during the seventeenth century concerned man's passions and in particular their problematic relationship with reason (James 1998; 2012). Since antiquity moral philosophers have regarded human passions as destructive and, consequently, in need of being tamed; they were understood to be irrational and therefore opposed to reason. Moral philosophers preached that wisdom and reason-the pathways to virtue, harmony, and tranquillity-were the means to regulate unruly passions. Only few people were expected to be capable of such self-management through restraint and the exercise of reason. Once philosophers started to accept the impotence of reason, however, they had to find alternative means to control the passions.

In relation to this, another hotly debated issue concerned the relationship between rulers and the ruled, and the influence of this relationship on the form of government. If the majority of people need the guiding hand of a ruler or ruling elite to control their passions, what assurance is there that government control does not turn into oppression? Views on such guidance ranged between political structures of repression and manipulation (i.e., to refashion the coarse clay of human nature into harmlessness) to providential arrangements (i.e., through which incongruent and disruptive elements were built into a coherent whole to the good of society).

The French moral tradition, which was actively engaged in these debates, had roots in Augustinianism; these roots influenced Mandeville's thought through the work of Jansenist philosophers like Pascal, Nicole, and Domat. Jansenism represented the religious views of Cornelis Jansen (1585-1638), who proclaimed a strict interpretation of St. Augustine's doctrine of grace in his posthumously published Augustinus (1640). Jansenist teachings clashed with the humanist views of the Jesuits, resulting in controversies with Jansenist protagonists (Sedgwick 1977). 
Jansenists defended the Augustinian theory that God's grace is necessary for the salvation of man; this conflicts with the Jesuit position, which stressed the possibility of salvation by man's own efforts. The latter point of view also features in Aquinas's work who, by allowing man to contribute to his salvation by his own efforts, tied "the natural to the divine by an unbroken rising scale of perfections" (Horne 1978, 21). By contrast, Jansenism stressed the impotence of reason and the all-powerful force of human passions in the fallen state, from which there is no redemption except through God's grace. There is no stairway to heaven for fallen man to bridge the gulf between himself and God. In his fallen state man is driven only by self-love, which corrupts his reason and infects his passions. As humans favour amour-propre while feigning love for God, Pascal states, "[w]e are only falsehood, duplicity, contradiction" (1958, 102). Given such depravity, Jansenist authors sought to expose the way humans masquerade and pretend, pointing out how seemingly virtuous acts are motivated by self-love.

Jansenists levelled their criticism at Stoic philosophy for their belief that virtue was within man's reach. Stoic ethics is founded upon selflove and seeks to subdue affections by acquiring independence from external factors. Although it is in essence an egoistic philosophy, Stoic philosophers argued that self-love was supposed to extend beyond itself and embrace family, friends, fellow-citizens, and the whole of humanity. Acknowledging that such extension grows weaker with social distance, it is the individual's task to love others as oneself.

Given the supposition of man's fallen nature, Jansenists contended that virtue is presumptuous and a sign of the same pride that brought Fall upon Adam (Brooke 2012, xiv). The Stoic belief that humans are capable of practising virtue only proves that humans are incapable of understanding their own self-centred nature. Pierre Nicole (1625-1695), who collaborated with Pascal, described man's self-love as follows:

corrupt man not only loves himself but loves himself beyond measure, loves only himself, and relates everything to himself. He wants every kind of property, honor, and pleasure, and wants them only for himself. Placing himself at the center of everything, he would like to rule over everything and wishes that all creatures were occupied with nothing but pleasing him, praising him, and admiring him (Nicole 1696, III: ch. 1 'Of charity and self-love'). 
The real motive to act virtuously is the human desire for esteem and glory; by consequence virtue is an act of pretence, a masquerade performed for the sake of hiding underlying motives of self-love.

If virtue is understood as such, and humans are driven solely by motives of self-love, then how to arrive at social order? Elaborating upon Pascal, Pierre Nicole combined Augustinian theory with Hobbesian political analysis. As Keohane described it, "[t]his devout disciple of the bishop of Hippo explored the alleys and byways of the City of the Earth with the author of the Leviathan for a guide" (1980, 294). Nicole describes admiringly the way nature providentially makes self-love imitate charity such that the outward effects of selfishness cannot be distinguished from those of charity. Virtuous outcomes result from actions rooted in vicious motives. Although Nicole does not elaborate upon the societal mechanisms that bring such effects about, it is apparent that this is 'private vices, public benefits' in the making.

In this way Jansenism shared fundamental beliefs with scepticism, a philosophy which dates back to classical antiquity, but which had revived with the writings of Montaigne (Burke 1981). Scepticism held that truth is, in the words of Montaigne, "not capable of attainment," and that it is "overbold vanity" to claim to have found it (1957, bk. 2, ch. 12). This means that again and again judgement needs to be suspended. Suspension of judgment also applies to virtue: what appears to be good is not necessarily good. Montaigne portrays humans as engaged in the art of self-deception, which seems to come natural to us given that we often claim to act on more lofty motives than agrees with true selfknowledge. We are keen to present to the world a much more virtuous, other-regarding, and publicly-spirited image of ourselves than truth permits. Montaigne observed that virtue and vice are often difficult to distinguish since behaviour that originates in unsound passions and desires may very well lead to socially desirable results, "as are poisons for the preservation of our health" (Montaigne 1957, bk. 3, ch. 1).

This idea resonates throughout Jansenist thought. In one of his Pensées Pascal thus notes that, "[w]e do not sustain ourselves in virtue by our own strength, but by the balancing of two opposed vices, just as we remain upright amidst two contrary gales. Remove one of the vices, and we fall into the other" (Pascal 1958, 99, no. 359). Traditionally, the most widely recommended way to control the passions was by appeal to wisdom and reason, and through self-discipline and education (or divine grace). Given the strenuous demands placed upon rationality, the 
seventeenth century witnessed increasing consideration for the possibility of manipulating human passions. To this end, politics were regarded as an art, a means to create a framework of rules to constrain the passions for the benefit of the common good. Pascal and Nicole thus emphasized the need for government regulation to control the human passions, using fear and force, as well as glamour and greatness.

Many of the Jansenist themes concerning social and moral issues make their appearance in Mandeville's work-e.g., the predominant role of the passions in analysing the human condition; the austere definition of virtue; the idea that social benefits may arise from (natural and moral) evils; the hypocrisy of man, and his attempts to masquerade his true, selfish desires. The influence of this tradition on Mandeville's thought is undeniable. ${ }^{1}$

However, this paper contends that we should be careful not to overstate the influence of Jansenist-Augustinian tradition on Mandeville, or to dismiss aspects of Mandeville's philosophy that do not fit the Augustinian frame. In Augustinian thought (and certainly in its austere Jansenist version) there is an unbridgeable gap between the moral standard by which humans are expected to live, and the assumption that the wretchedness of human nature will preclude any such achievement of that standard. The logic of the Augustinian analysis was built upon the fundamental idea that there is a strict separation between the love of God, the heavenly city, and the order of charity and self-love, the city of the earth, and the world of concupiscence. Mandeville, by contrast, did not accept the uncompromising existence of two separate worlds but allowed virtue to develop from the wretchedness and presumptuous nature of man. As Colman observed in discussing whether Mandeville's views on morality allowed for the reality of virtue, "[i]t would be a mistake [...] to suppose Mandeville a serious Augustinian in morals" $(1972,129)$.

In many ways Augustinian theory voiced concerns about change and its effects upon man and society, uncomfortable with the way moral

\footnotetext{
${ }^{1}$ This influence was immediately identified by contemporaries like Blewitt and Law (Horne 1978, 19). Kaye emphasized Mandeville's indebtedness to the French moral tradition, bluntly stating that, "[t]he great source of Mandeville's psychology was France" (Kaye 1924, xciv). Such claims usually include a reference to Pierre Bayle, an Augustinian-Calvinist who fled France because of its religious intolerance and dogmatism, who lectured at the 'Illustre School' in Rotterdam in the 1680s and early 1690s (Cook 2007, 398-399). In Free thoughts on religion, the church and national happiness, Mandeville stated that he had "made great use of Monsieur Baile" (1720, xx; see also James 1975). More recently, Mandeville was put firmly in the camp of the neoAugustinians by Pierre Force (2003).
} 
views were adapted to changing conditions. Jansenists were wary of society and its ideals, and thus were critical of notions of politeness, glory, and honour among the political aristocratic elite, denouncing its underlying self-regarding and self-congratulatory nature. Mandeville, by contrast, accepted that society had irrevocably changed, thereby putting strain upon traditional views and beliefs. Commercial society did not fit the traditional Augustinian scheme of interpretation and so the exploration of new ideas would induce conflict. Uncomfortably, the commonwealth became rich and powerful from the bustling commerce of greedy and ambitious individuals, defying any direct link between private morality and the public good. With the rise of a commercial and professional class, commercial society also dismantled the traditional distinction between the ruling elite and mass of labouring poor. All of these developments required new answers to old questions. Debate focused on the measure of self-love compatible with peace, order and commodious living rather than the choice between two worlds. Given that reason was increasingly deemed inadequate for controlling drives and desires, a reformulation of the function and role of the passions took place. Far from being vice-ridden and disruptive, passions were increasingly seen as instruments of virtue. With this reassessment of the passions, debates gradually shifted and focused on the question of how to encourage the 'good' passions and discourage and divert the 'wrong' passions.

Given the extenuating implications of such accounts, claims were carefully scrutinized and the same passion could be assigned a taming role as well as a disruptive one. This fate befell the passions of ambition, vanity, honour, and glory, all lumped together as the love of praise or pride, expressing one of man's most defining features: the need for approbation. Differently assessed, the same need for approbation inspired diametrically opposing views (Lovejoy 1961). One view took the need for the approbation of others as intrinsic motivation to comply with norms and rules. As such, pride or the love of praise was a useful substitute for virtue and, even though the motive may be questionable, the effects of such self-serving motives were indistinguishable from that of virtuous motives. Efforts to satisfy one's need for approbation, moreover, brought about public benefits, which in turn strengthened rule-following and mutual trust. Others, however, viewed the need for approbation unfavourably as it tended to transform itself ever so smoothly into self-aggrandizement, and further, into a 
desire for distinction and superiority. This paved the way for such passions as jealousy, envy, and hypocrisy to arise and facilitated emulation, discord, and moral corruption in society as people tried to exploit one another's desire for praise and esteem.

In sum, if the French moral tradition is seen to represent a grim social and moral philosophical standard, the brothers De la Court (as the next section aims to show) represent the converse position, arguing for a positive theory of man's drive for honour and pride.

\section{THE BROTHERS DE LA COURT, PASSIONS, AND POLITICAL THEORY}

The issue of the regulation of human passions was often investigated, and hence associated, with the issue of the relationship between rulers and ruled, forms of government and public spirit. With regard to these issues, the seventeenth century hosted several discourses, each with its own assumptions and specialized vocabulary.

Classical republicanism, for example, is committed to the ideals of virtue and liberty, and seeks to identify the conditions under which the politics of the organization of society is conducive to each individual's quest for virtue and happiness (Pocock 1975; 1985). It heralds active participation in public life as well as the government of the (city) state, and focuses on man's political personality. Humans are political animals and therefore must be active in the public domain in order to reach their potential. Virtue consists in the practice of reason and self-government; this is the key to regulating one's impulses and subordinating their own interests to the greater public good. Citizens in a free political community ought to be not only publicly-spirited, but also need to be capable of participating in the public domain without being tied down by efforts to secure subsistence. If private interests infringe on public duties, the political community may become corrupted, undermining community welfare. As such, classical republicanism was hostile towards the commercial society: the seeking of wealth and luxury undermined the civic virtues that were seen as necessary for the realization of a free and virtuous political community. The poet John Milton, who celebrated the agrarian, anti-commercialistic spirit of Sparta over the commercialistic Athens, argued that the commercial man set "the Common-wealth behind, his private ends before, to do as his profit or ambition led him" (quoted in Pincus 1998, 714). Thus, commercial society and its political economy was condemned for enabling men to 
become engrossed by the pursuit of private gain to the neglect of the public good.

Jonathan Israel (2004) has argued that Dutch republicanism should be carefully distinguished from Anglo-American republicanism, and that it is to be understood as the prime root of modernity, due to its commercialism as well as its anti-hierarchical and anti-monarchical views. Furthermore, it has been argued that commercial republicanism regarded trade as the true basis and safety of any commonwealth (Weststeijn 2012). Trade, and the flows of income it generated, was the means to the ends of civil liberty, power, and wealth. Trade was the true interest of a country and, on the basis of this belief, praises for merchants and tradesmen increased as their importance for commonwealth was recognized (Pincus 1998). Authors enlarged upon the social benefits of trade, some anticipating Montesquieu and Hume in arguing that "care to increase manufacturie ought to be had, for that enricheth and civilizeth the people" (Streater, quoted in Pincus 1998, 722).

Whereas classical republicanism considered interest to be incompatible with the virtues of civility and public spirit, commercial republicanism adopted the spirit (and language) of interest. Commercial society required its own politics. Nedham recorded the rationale for the language of interest. Virtue, he felt, probably was an unreasonable ideal; but if man could not be made virtuous, he could be (made) useful. "The greater part of the world," he wrote, "[was] led more by appetites of convenience and commodity, than the dictates of conscience," so why not tell "men what will be profitable and convenient for them to do, than what they ought to do" (quoted in Pincus 1998, 729). Such ideas, Pincus adds, were accompanied by the notion that "virtue is a contingent concept, contingent on social, economic, and geopolitical considerations" rather than "a timeless concept with a precise set of classical or Christian meanings" (1998, 729n128). The brothers De la Court had a prominent place in the development of (Dutch) commercial republicanism and their writings are widely recognized as key texts in republican discourse (Wildenberg 1986).

Pieter (1618-1685) and Johan de la Court (1622-1660) were born in Leiden. In the first part of the seventeenth century Leiden was a prominent industrial town, which had built its prosperity upon the textile industry. Following in their father's footsteps, the brothers became cloth manufacturers and merchants, and "part of the intellectual and 
entrepreneurial avant-garde of the period" (Blom and Wildenberg 1986, 195). Though they were successful merchants, they lacked the background and clout to join the political elite; nevertheless, they called for freedom from the regulations and control by the Leiden authorities, corporations, and guilds, posing a challenge to preferential arrangements and privileges. Shortly after Johan's death in 1660, Pieter published anonymously a manuscript largely written by his brother. In the following years Pieter revised and extended their views, ${ }^{2}$ gaining a reputation as a missionary of commercial republicanism. After the murder of the brothers De Witt in 1672, Pieter fled to Antwerp, only to return to Leiden a year later, where he died in 1685.

The brothers De la Court developed their commercial republicanism by drawing ideas from various sources, ranging from authors in the republican tradition as well as new ideas and visions that developed with changing circumstances in the seventeenth century: from Guicciardini, they learned to apply the concept of interest to politics; from Machiavelli, they understood politics to be about the effective use of power to manipulate fortune and to serve the commonwealth rather than the art of governance to promote virtue and justice; and, with Hobbes, they agreed that humans are natural egoists, and that a political society is necessary for cooperation and growth.

Intent on explaining the best form of government to maintain the commonwealth in a healthy condition, the De la Courts embraced a Cartesian psychology as expounded in his Les passions de l'âme (1649; cf., Kossmann 1960; Cook 2002; 2007). Descartes regarded the passions as the intermediaries between body and soul, motivating humans into action and directing them towards that which nature deems useful to us. Nevertheless, Descartes acknowledged that the passions may easily lead

\footnotetext{
${ }^{2}$ He published various editions of Consideratien van staat, ofte polityke weeg-schaal (Considerations of state, or political balance) in 1660-1662, Politike discoursen (Political discourses) in 1662-1663, Interest van Holland, ofte gronden van Hollands-welvaren (Interest of Holland, or foundations of the well-being of Holland) in 1662 (with two chapters written by Johan de Witt), of which a revised edition was published in 1669 as Aanwysing der heilsame politike gronden en maximen van de republike van Holland en West-Vriesland (Demonstration of the benificient political foundations and maximes of the republic of Holland and West Frisia), and Sinryke fabulen (Significant fables) in 1685. Given their close collaboration, it is often impossible to say which part was written by which brother. In this paper I consequently follow common practice to refer to 'the De la Courts', while referring to 'de la Court' only when dealing with revisions made (politike weeg-schaal) and new material written by Pieter (Interest van Holland, aanwysing, and Sinryke fabulen) after Johan's death in 1660.
} 
one astray. ${ }^{3}$ Consequently he emphasized the need to control the passions through experience, reason and by pitting passions against passions.

Building upon the Cartesian theory of the passions, the De la Courts agreed that it is only by nurturing the passions through a process of learning and socialization (education, experience, and reasoning) that man learns the true use of his passions; this is how the passionate man becomes rational. Nevertheless, they were less optimistic about the success of the individual's own efforts. Biased by self-love, man cannot be relied upon to control his passions (Johan and Pieter de la Court 1662a, I.I.1:13-15) from which the brothers deduced the need for the state to create a framework of reason to reign over the passions (1662a, I.I.3). The quality of government is thus measured by the extent to which it is capable of controlling the passions (1662a, I.I.5:33). Some forms of government are better than others at creating an institutional structure that promotes the 'right' passions and discourages destructive passions. As such "passions and institutions are interdependent", whereby the De la Courts emphasized "the social setting of the passions" (Blom 1995, 177).

The De la Courts elaborated further on the idea of the neutralizing effect of pitting passions against passions by taking it from the level of the individual to the level of political society. The best state is that state in which the passions of its members constantly clash, thereby rendering them harmless. As the Scottish philosopher Adam Ferguson stated in his Essay on the history of civil society: "The public interest is often secure, not because individuals are disposed to regard it as the end of their conduct, but because each, in his place, is determined to preserve his Own" (1980, prt. III, sect. II:128). Divergent interests mutually check each other and force upon one another arrangements which safeguard the public interest: discord is the linchpin of the health of the commonwealth:

in an assembly of equally powerful Members, there is always a large variety of passions, which keep each other in check without insight of own benefit. Thus, when it comes to political matters, reason finds

\footnotetext{
${ }^{3}$ In medicine, health was considered to depend upon the proper balance of mind and body. Disease was the result of an imbalance, arising from errors of judgments that led the individual to act in ways that are not beneficial. It is one thing to know what is right and in accord with reason; it is quite another to act in accordance with reason. This is only possible by controlling the passions. A good life and health, which lead to both physical and moral goodness, were thought to require that one's physical and mental life (mind, passions, and body) was regulated adequately. Such ideas proved attractive as metaphors and were useful to discuss the state of the commonwealth in terms of the health of a political body made up of various interacting parts (Cook 2002; 2007).
} 
always more place in legitimate assemblies than in one man, whose judgment is frequently stunned by the passions (Johan and Pieter de la Court 1662a, II.I.3:320-321; transl. in Weststeijn 2012, 264-265).

The De la Courts explored whether monarchical or republican rule is best suited to guide passions into useful channels in the long run. This exploration resulted in a rejection of monarchical rule. In a monarchy people are at the mercy of the passions of the ruler. If these passions go unchecked by mutual rivalry, a monarchy fails to create a rational balance; it disrupts the incentives and interests of its subjects, whereby the commonwealth underperforms in terms of its level of wealth and civilization. Given the tendency of persons to use power to their own advantage, a true political system secures itself against the abuse of power. This is only possible, De la Court insists, if the interests of rulers and subjects align:

The interest of every country consists in the well-being of its rulers and subjects together, and it is dependent on a good form of government, and therefore that is the foundation on which the wellbeing of the commonwealth is built; so one has to understand, that a good form of government is not where the well- or ill-being of the subjects depends on the virtue or vice of the rulers, but (and this should be noted) where the well- and ill-being of the rulers, by necessity follows from, or depends on the well- or ill-being of the subjects (De la Court 1671, 2; transl. in Blom 1995, 178).

Self-interest, properly understood, is defined in terms of an intimate and positive relationship between the well-being of the subjects and rulers alike, between private advantage and common welfare, and implies harmony of interests (Weststeijn 2010, 84). As such self-interest is a basic constituent element of the health of the commonwealth, which should not be upset by the whims of rulers indulging their private passions and securing their benefits at the expense of the subjects.

From this brief description of the De la Courts' political theory one might easily get the impression that if Mandeville was influenced by the ideas of the De la Court brothers, it was because he developed his views in contradiction to theirs. For example, instead of emphasizing the public benefits that arise from proper control of the passions, he argued that society benefits from arousing the passions. Furthermore, Mandeville did not insist on the mutual well-being of the individual and collective: "They are silly People who image, that the Good of the Whole is consistent with the Good of every Individual" (Mandeville 1953, 45n1). Moreover, 
Mandeville did not share the brothers' belief that only a republican form of government can control the passions properly. The De la Courts took great pains to sketch in stark moral colours the differences between republic and monarchy. They claimed that the latter encouraged, rather than restrained, man's passions to the effect that under monarchical rule "a country will be filled with Fops, Dancers, Players, Cursers, Fornicators, Hunters, Gluttons, and Boozers \&c" (Johan and Pieter de la Court 1662a, I.I.14:82-83; transl. in Weststeijn 2012, 182). The writings of the brothers De la Court were designed to impress this message upon its readers. If it was not the De la Courts' political theory that influenced Mandeville's thought, what was it that provided Mandeville with the springboard to arrive at his own theory? To answer this question, we first need to inquire into the De la Courts' social and moral theory.

\section{THE POSITIVE THEORY OF INTEREST AND PASSION}

Mandeville was fascinated by the discrepancies between what people believed in and how they acted, between intentions and outcomes, between motivation and justification and in particular by the way these social mechanisms were founded upon such discrepancies. As such, he was not so much interested in contrasting the "city of God" with the "worldly city" (and thus lamenting the loss of the order of charity), but in questioning how a world of order, peace, and commodious living could emerge from the selfish impulses of men. One does not have to agree with their political ideas to recognize the work of the brothers De la Court as a rich source of ideas; it was this work that provided Mandeville with a positive theory of interest and the passions, thereby complementing the negative theory of the neo-Augustinians.

The use of the concept of interest is usually traced to the work of Guicciardini (1483-1540). This Florentine aristocrat and member of the commercial elite started to apply the language of commerce to political analysis (Gilbert 1965; Viroli 1992). Identifying interest as the driving force in human affairs, he argued that interest was a justifiable principle of human conduct, if restrained and moderated by honour, encouraging actions that promote the public good (McKenzie 1981). Guicciardini emphasized that interest should not be narrowly interpreted as the pursuit of material gain (false interest), but insisted on the need to keep self-interest within the bounds set by the aristocratic code of honour (man's true interest). If interest is the motivating force behind human behaviour, then channelling interest in a socially and politically 
constructive direction requires that people be persuaded that honour and its restraining influence upon behaviour serve their purposes. Thus Guicciardini developed the argument that honour is profitable:

In this world of ours, the men who do well are those who always have their own interests in mind and measure all their actions accordingly. But it is a great error not to know where true interest lies; that is, to think it always resides in some pecuniary advantage rather than in honor, in knowing how to keep a reputation, and in a good name (Guicciardini, quoted in McKenzie 1981, 282).

Much like basic conflicts articulated in other discourses (as between passions and reason/virtue, or self-love and love of God), the 'language of interest' also exhibited such a conflict: the disparity between private (self) interest and common interest. Thus, self-love was seen to drive man towards a narrow understanding of (self) interest that puts the individual in opposition to the community. Self-love here portrays the human as an individual with passions and desires that set him apart from others instead of being a cohesive part of a larger whole. Love of self causes individuals to turn inward, causes them to be aware only of their own particular needs and desires (vis-à-vis the needs and desires of others). If self-love dominates behaviour, it tends to focus on gaining profit, or advantage of some form, for that particular self. This tension establishes the need for a distinction between true and false self-love (or self-interest).

By acknowledging self-love as "the true origin of all human actions" (Johan and Pieter de la Court 1662a, I.I.1:13; transl. in Weststeijn 2012, 169), the brothers De la Court carefully distinguished between excessive and vicious self-love, and between its moderate and true forms. Rather than relying on God's grace to overcome self-love, the brothers argued in Stoic fashion that, "well-founded Self-love is the root of all laudable outward deeds" (Het welvaren van Leiden, quoted in Weststeijn 2012, 169). For this reason, the love of the self was to extend itself to embrace family, neighbours, fellow-citizens, and all of humanity. The brothers drew together the two assessments of man's desire for praise and approbation by distinguishing between the desire for honour (true selflove) and the desire to rule (false self-love). The desire for honour, praise, and esteem acts as a powerful incentive to virtuous acts, and therefore induces people to restrain their self-love and to take care not to harm others in the pursuit of private desires. However, this all too human passion may be corrupted and develop into the "desire to rise above those 
who are truly equal to them" (De la Court 1685, 86-87; transl. in Weststeijn 2012, 171). This excessive form of self-love and ambition turns the 'desire for honour' into the 'desire to rule'. The De la Court brothers emphasized that the "crucial means to overcome the corruptive potential of the passions of self-love lies in the disciplinary framework that is established with the creation of civil society" (Johan and Pieter de la Court 1662a, I.I.3; transl. in Weststeijn 2012, 177). Given man's selflove, ambition, and greed, the De la Courts describe how, in the growth of society, a political framework is created by common agreement to end conditions of fear and war. This framework allows for civic instruction and the establishment of the rule of law to turn self-love into self-interest (defined as interdependent well-being). The brothers derived much of their perspective on the nature of man and political society from their teacher at the University of Leiden, Marcus Boxhorn. ${ }^{4}$

In his study on Boxhorn, Nieuwstraten has argued that Boxhorn "laid the groundwork for future Dutch political thinkers such as the brothers De la Court and Spinoza" (Nieuwstraten 2012, 243). Boxhorn did away with the customary, Aristotelian claim that man was a political animal, inclined to society from his natural sociability. Instead he explained political society from man's unsociability and developed a positive notion of the commonwealth, founded upon the self-interest of its members.

Developing independently a similar account of the rise of political society as did Hobbes, Boxhorn reasoned, starting from a few, basic principles, that human nature tends toward a state of war. By nature all humans are equal, free, and driven by egoistic impulses, ridden with ambition and greed: "Where everyone is permitted everything, everyone will want to take possession of everything and will continuously strive for more" (Boxhorn, quoted in Nieuwstraten 2012, 254). Boxhorn described how the golden age comes to an end with the growth of families beyond the means of subsistence, which requires them to split and divide possessions. The introduction of private property required laws for protection. This rule of reason, however, was broken down by dissent and

\footnotetext{
${ }^{4}$ Marcus Zuerius Boxhorn (1612-1653) was born in Bergen op Zoom as the son of a minister of the Reformed Church. He enrolled at the University of Leiden in 1626, taking the arts programme first, proceeding to study theology, which he quit within the year. At the age of twenty he became lecturer of eloquence. In 1640 he was appointed professor of eloquence, increasingly extending his field into history. Among his students were the brothers De la Court and Johan de Witt. Boxhorn's main political works were (both published posthumously) Institutiones politicae (1650), partly written around 1641 before Hobbes's De cive (1642) and Leviathan (1651), and Disquisitiones politicae (1669). This part of the paper relies on Nieuwstraten's study on Boxhorn (2012).
} 
violations, resulting in factions and war. By nature, humans are least fit to live in society, but are forced to pull together in a commonwealth out of fear and the advantage of numbers: political society is rooted in man's unsociability.

Boxhorn defines a commonwealth as "a body of many that is permeated by the same laws for the sake of the advantage of all together and each individually to recognize the majesty of the power to command over that same body" (Boxhorn, transl. in Nieuwstraten 2012, 258). Boxhorn thus insisted on the intimate relationship of private and common interest to the maintenance of the commonwealth. Arguing the prime importance of the rule of law, Boxhorn warned against "ambitious princes who, poisoned by the adulation of flatterers, seek to enlarge their power and to rule as they please" (Nieuwstraten 2012, 269). Taking the wellbeing of the commonwealth as the measure of right and wrong, he recommended that political participation would induce obedience (more so than rule of religion and law): stability increases when people commit themselves by being personally involved in government. That is why a commonwealth needs to ensure the advantage of all together, as opposed to the welfare of one at the expense of the many. With such views Boxhorn proposed a positive theory of interest, presenting "self-interest as the pillar of peace" (Nieuwstraten 2012, 282).

Following Boxhorn, the brothers De la Court developed their own theory of interest and the passions, differentiating between true self-love (interest) and false self-love (interest) in connection with various types of government. In this context another key-idea of Boxhorn proved useful: the notion that ideas, institutions, and forms of government, as well as their underlying principles, should be understood as consequences of ever-changing conditions of time and place (Nieuwstraten 2012, 324).

This key idea was also basic to Lambert van Velthuysen's views on man's sociability, another important source for the political theory of the De la Courts. Although he provoked controversy for defending Hobbesian and Cartesian principles (Blom 1995, 106), Velthuysen went beyond both philosophers, thus anticipating Mandeville, by offering a naturalistic and empirical account of sociability. ${ }^{5}$ Starting with the assumption that man is

\footnotetext{
${ }^{5}$ Lambert van Velthuysen (1622-1685) studied medicine at Utrecht and law in Leiden, receiving his doctorate in 1650. Many of his publications were at the heart of theological and philosophical controversies which raged in 17th-century Holland. Practicing the medical profession left him time for governmental activities, and between 1660 and 1672 he was mayor in Utrecht (Velthuysen 2013; Frijhoff and Spies 2004; Blom 1995).
} 
driven by the passions, which are themselves an expression of selfpreservation and selfishness, Velthuysen groped towards a naturalistic account of sociability and morality in response to changing historical formations. Given the historical specificity of conduct, rules, and morality, Velthuysen emphasized the need for empirical facts about man and society rather than reason or revelation.

Blom (1995) relates Velthuysen's views on the passions to the Stoic notion of the purposeful order of nature. However indirect and likely to fail, passions direct us towards self-preservation: they are natural and positive drivers towards the (unknown) purpose of God's creation. With this positive view of the function of man's passions, Velthuysen constructed his naturalistic account of sociability.

One of the issues in his account which intrigued Velthuysen was the question of how to explain sociability given man's essentially egoistic nature. He emphasized the essential role of the passion of shame. Velthuysen separated morality from theology, arguing that, in many cases shame is not related to sin but is a demonstration of (the violation of) the rules of proper conduct, defined in a specific cultural and historical context (Blom 1995, 121). Shame lies at the heart of the mechanism through which sociability is developed. Shameless behaviour gives rise to disapprobation and contempt from others. Such responses conflict with man's sense of worth and self-esteem, and are best avoided. Consequently, Velthuysen "stresses as the dominant mechanism the interaction of men among each other", inducing people to reckon with one another in their decisions and actions (Blom 1995, 123). Velthuysen argued that sociability and morality develop naturally from man's drive for self-preservation in a changing historical context.

Claiming that political society originates in mutual fear (Johan and Pieter de la Court 1662a, I.I.3:21-23), the De la Courts argued in line with Velthuysen that fear may also bring about the sociability necessary to build together a cooperative framework to allow everyone to share in the benefits. Fear awakens a natural reasonableness which brings people to enter into an agreement. Sociability is the natural outcome of man's selfregarding passions, involving a process through which people develop a fitness for society (without the need to have recourse to benevolence).

When driven by self-love, humans become sociable given their common fears and needs. This allows for the rise of a framework of cooperation, which in turn, develops into a political and moral framework that educates people to understand the strict connection between their 
own interests and wellbeing and that of the commonwealth. The brothers De la Court emphasized this interdependence of human passions and political institutions; they argued that the destructive / constructive tendencies of the passions vary in accordance with different forms of government. They differentiate it as follows: ${ }^{6}$

$\begin{array}{ll}\begin{array}{l}\text { True self-love } \\ \text { (moderated by the desire for honour) }\end{array} & \begin{array}{l}\text { Excessive self-love } \\ \text { (expressed in the desire to rule) }\end{array} \\ \text { True (common) interest } & \text { False (selfish) interest } \\ \begin{array}{l}\text { Frugality } \\ \text { Passions properly controlled }\end{array} & \begin{array}{l}\text { Extravagance } \\ \text { Wrong passions encouraged }\end{array} \\ \begin{array}{l}\text { Conditions intimately linked to: } \\ \text { Republic without a stadholder }\end{array} & \text { Monarchy }\end{array}$

In arguing for commercial republicanism the brothers De la Court defined the conditions under which self-love is justifiable: self-love, as expressed by the passions, needs to be controlled through political organization; different forms of government perform differently in maintaining the health and wealth of the commonwealth. By employing the language of interest, the logic and design of their argument was to identify and link the (moderate, honourable, and true) interests of subjects and rulers, and to unite this relationship with the republican form of government and its institutions. Their claim was that only a republic (without a stadholder) fulfils the conditions to control the passions such that the health and wealth of the commonwealth is secured.

\section{MANDEVILLE'S NEW LOGIC}

Although both share the notion of self-love as (fallen) man's basic drive, the brothers' positive theory of self-love and interest contrasts with the neo-Augustinian logic of the French moral tradition. While the De la Courts defined the conditions under which self-love and gain are justifiable, the neo-Augustinians reasoned that however glittering, and to what heights self-love may reach, the self-love of fallen man is fundamentally flawed. This contrast is particularly apparent in the assessment of vanity and pride in both discourses. The desire for approbation and esteem, described by the brothers De la Court as motive

\footnotetext{
${ }^{6}$ In his Sinryke fabulen (1685; published as Fables, moral and political, with large explications in England in 1703) Pieter de la Court offered short stories, in which contrasts are drawn to argue the case for true self-love, interest, honesty, and especially the republican state.
} 
for virtue, is denigrated in the French moral tradition as the desire for distinction and superiority (as it is often masked by politeness and sign of moral corruption). Mandeville's analysis of commercial society is founded upon both the negative and positive theories of interest and passions. He understands both orientations as opposing tendencies that dwell within man and society-these tendencies produce the dynamics which shape society (Verburg 2015). For this reason, it would misconstrue Mandeville's thought to emphasize the neo-Augustinian tradition without giving due consideration to the commercial republicanism of the De la Courts. Let us analyse both approaches in turn to see how Mandeville constructed a new logic of (self-)interest, morality, and society.

Mandeville applied an evolutionary perspective to the positive theory: he argued that the passions gradually acquired a positive social function in society, which was a result of the dynamics between passions, changing circumstances, and institutions. Taking human nature as fundamentally egoistic, Mandeville rejected the Hobbesian claim that, given man's unsociability, political society is a human contrivance. Following Boxhorn, Velthuysen, and the De la Courts, he sketched a theory which depicted the growth of society, and man's fitness for society, as an unintended consequence of human efforts to adjust to a state of association and interdependence, once man is driven towards society from necessity. As the body politic grows in population, commerce, and complexity (due to the differentiation and diversification of tasks and labours), people increasingly depend on one another to satisfy their needs and desires. Dependence works wonders for man's social skills. Mandeville describes human's sociability and susceptibility to social constraints as born out of the need for co-operation in the face of dependence. In this evolutionary process, human's natural and unsocial impulses are moulded and disciplined through an evolving framework of laws and institutions. In the growth of civilization, potentially destructive passions are thus transformed into an integrative force.

However, Mandeville's positive account of interest and the passions does not imply a tendency toward human perfection. Here we encounter the second leg of Mandeville's frame of thought: the neo-Augustinian, negative theory of interest and the passions. Mandeville takes every opportunity to expand upon the hypocrisy, insincerity, discord, and vice by which human behaviour is tainted. People everywhere seem to be motivated to satisfy their selfish desires for distinction and superiority at the expense of others. Moreover, given the division of labour in 
society, moreover, people have different interests and consequently are differently affected by events: the loss and misfortune of the one is often the advantage of the other. The interdependence of private wellbeing and collective well-being that the brothers De la Court emphasize in their notion of interest is wholly absent here. Mandeville ridiculed the view that "the means of thriving and whatever conduces to the Welfare and real Happiness of private Families must have the same Effect upon the whole Society" (Mandeville 1988, I: 354-355). This disparity between the realms of the individual and that of the collective not only exists in the economic sphere but also in the moral sphere. In a large and impersonal society-one in which tasks are differentiated-actions not only have unforeseen and unintended consequences, they also have differential effects across the population. Virtuous actions, and likewise vicious actions, may both harm and promote the public good. As Mandeville contended:

It is in Morality as it is in Nature, there is nothing so perfectly good in creatures that it cannot be hurtful to any one of the Society, nor any thing so entirely Evil, but it may prove beneficial to some part or other of the Creation: So that things are only Good and Evil in reference to something else, and according to the Light and Position they are placed in (I: 367 ).

In commercial society there is no necessary connection between private morality and public benefits. This characteristic feature of commercial society defies the neo-Augustinian logic based on an unbridgeable gulf between the world of charity and the world of concupiscence, contrasting virtue with self-love. Any appeal to virtue or reason for the purpose of improving public well-being is beside the point. It is equally misplaced to think, as the brothers De la Court did, that any regulative government framework could regulate human passions to make them conducive to public well-being: identification and arrangement of the passions defies human understanding and knowledge. Concluding that private virtue would not secure the benefits of (commercial) society, Mandeville turned the question around. Instead of starting from virtue to inquire into the opportunities and limitations of commercial society, he asked himself whether the passions, desires, and interests that make commercial society work would engender virtuous behaviour. That is, if the wealth and health of commercial society cannot be secured by way of virtue, to what extent can virtuous behaviour be secured by way of the 
pursuit of the wealth and health of society? Framing the question in this way, Mandeville constructed a new logic from elements of both constituent logics.

The De la Courts had argued that although humans are not suited for society by their nature, they are made fit for it. Mandeville developed a similar argument. The essence of his argument can be found in his Fourth Dialogue (Mandeville 1988, II: 188-189):

Hor(atio): If I have not misunderstood you, you would insinuate two Things: First, that the Fitness of Man for Society, beyond other Animals, is something real; but that it is hardly perceptible in Individuals, before great Numbers of them are joyn'd together, and artfully manag'd. Secondly, that this real Something, this Sociableness, is a Compound, that consists in a Concurrence of several Things, and not in any one palpable Quality, that Man is endued with, and Brutes are destitute of.

Cleo(menes): You are perfectly right: Every Grape contains a small Quantity of Juice, and when great Heaps of them are squeez'd together, they yield a Liquor, which by skillful Management may be made into Wine: But if we consider, how necessary Fermentation is to the Vinosity of the Liquor, I mean, how essential it is to its being Wine; it will be evident to us, that without great Impropriety of Speech, it cannot be said, that in every Grape there is Wine.

Horatio comments that to make the claim that the sociableness of men may be compared to the Vinosity of Wine, requires the identification of an 'Equivalent for Fermentation' in society. In his answer, Cleomenes points at mutual Commerce: "Men become sociable, by living together in Society" (II: 189). Mandeville thus underlines Velthuysen's emphasis on the interaction among men in the growth of man's sociability. How does this mechanism work? How do humans become socialized, moral beings?

Taking man as a "Compound of various Passions" (I: 39) and untainted by illusions about human nature, Mandeville starts from the premise that humans are motivated by self-regarding passions: "Every Individual is a little World by itself, and all Creatures, as far as their Understanding and Abilities will let them, endeavour to make that Self happy: This in all of them is the continual Labour, and seems to be the whole Design of Life" (II: 178). The growth of civilization, according to Mandeville, is the result of an evolutionary process through which 
humans learn to accommodate their passionate drives in the context of increasing mutual dependence and become "a taught animal" (I: 286).

The development of man into "a Disciplin'd Creature" (I: 347) first awaited the rise of political society. In the second volume of the Fable of the bees (1727) Mandeville described the rise of political society in three stages. In the first stage families extended into groups or clans for protection against nature; such associations-different in cooperation and organization-generated claims of power and dominion. The resulting enmity (the second stage) required further collaboration out of mutual fear and protection against one another. The final stage in the formation of society is reached when the arts of speech and writing (as instruments of persuasion) enable the establishment of the rule of law by government. This serves as a common measure to settle conflicts and secure the advantages of society. In this way, Mandeville presents a historical account of the formation of society similar to Boxhorn (though in greater detail), arguing that society originates out of fear, necessity, and advantage. While he shared this view on the origins of society with Hobbes and the De la Courts, Mandeville did away with the notion of a social contract upon which society was founded, believing it absurd that man would have the insight to come to an agreement by sheer calculation of future benefits. If man is driven by self-regarding passions instead of reason, man could only become a disciplined creature by those passions. Thus, Mandeville attempted to identify the social mechanisms responsible for disciplining and socializing humans; his naturalistic perspective resembled that of Velthuysen and the brothers de la Court.

Nature, Mandeville informs us, has gifted man with two instincts: self-love and self-liking. Self-love is the emotional source from which all the wants and passions arise, instrumental in human preservation; while self-liking is an instinct "by which every Individual values itself above its own Worth" (II: 130). It was from the instinct of self-liking that politicians and moralists created a system of approbation and disapprobation, to guide humans towards behaviours that went against their natural inclinations. ${ }^{7}$ Aware of man's eagerness for praise and

\footnotetext{
${ }^{7}$ In An enquiry into the origin of honour, and the usefulness of Christianity in war (1971) Mandeville argued through Cleomenes that, in practice, the principle of honour is a much more effective system to restrain and direct human behaviour than Christianity. Honour as a principle of conduct was invented to control people after it had become apparent that other forms of authority, including Christianity, had failed to instil people with a proper regard for that authority out of a fear for death.
} 
esteem, they bestowed upon man so much flattery that he was inclined to overvalue his real worth (leading to excessive self-liking or pride). Equipped with an enlarged sense of self-liking, man becomes increasingly dependent on signs of approval and disapproval as he needs to continue to feed his pride and avoid any form of shame that might devalue his self-esteem.

Mandeville described pride and shame as "two Passions, in which the Seeds of most Virtues are contained" (I: 67). ${ }^{8}$ These passions were dictated by the instinct of self-liking and, as such, directed humans to observe rules in order to avoid shame by stifling their appetites and masking their true sentiments. In fact, shame was seen to be such a powerful emotional force that man endeavoured to preclude any attack upon his self-esteem by disguising his pride. Moreover, since brazen pride was offensive to others, man's love of ease accentuates this masquerading inclination. According to Mandeville, human hypocrisy to further self-interest becomes so extreme that some develop the habit of pretending to estimate the worth of others even higher than themselves.

At the same time man becomes increasingly conscious of the fact that his need for esteem is only gratified if he reckons in his competitive efforts with the same need in others. From experience man learns that sociability serves his self-interested purposes. Given that commercial society "is made up of the reciprocal Services, which Men do to each other", this sociability, called forth by man's need for the approbation of his fellows, is the means "to get these Services perform'd by others, when we have Occasion for them" (II: 349). In this process, man becomes "a Disciplin'd Creature, that can find his own Ends in Labouring for others, and where under one Head or other Form of Government each Member is render'd Subservient to the Whole, and all of them by cunning Management are made to Act as one" (I: 347). Man becomes a disciplined, socialized being, and in a way, also a moral being, by discovering the utility of restraining his self-motivated passions in his need for the approbation and assistance of his fellows (Jack 1975, 3738). By dexterous management of the passions, man is provided with a self-interested reason-the need to feed his enlarged sense of self-to act against his natural inclinations in order to contribute to the public

\footnotetext{
${ }^{8}$ Like Velthuysen, Mandeville noted the importance of the passion of shame: "it is incredible how necessary an Ingredient Shame is to make us sociable [...] no Society could be polish'd, if the Generality of Mankind were not subject to it" (Mandeville 1988, I: 68).
} 
good. Mandeville concluded that, "the Moral Virtues are the Political Offspring which Flattery begot upon Pride” (Mandeville 1988, I: 51).

Mandeville then was not so much interested in the character of the ruler and its effects upon the well- or ill-being of the commonwealth. Neither was he concerned with the composition of the ruling elite to guarantee that the interests of the ruler(s) were strictly tied to the interests of the subjects. And, he certainly did not endorse the position that the success of the commonwealth was dependent upon the effective curtailment of the passions by government. ${ }^{9}$ It is not by virtue that public benefits are secured. Although Mandeville conceded that man's passions were manipulated into the service of the public good, he argued that wise legislators and politicians utilize the passions by stirring them up, by transforming self-liking into pride, to spur man into being sensitive and responsive to others. People desire things and increasingly they need the help of others to get them, so they need to learn to be polite. The more desires multiply and diversify, the more people are interdependent and need to take one another into account, thereby becoming sociable, moral beings: "the Sociablenesss of Man arises only from these Two things, viz. the Multiplicity of his Desires and the continual Opposition he meets with in his Endeavours to gratify them" (I: 344). Morality is not absolute but contingent upon social, economic, and political circumstances; it is only when the passions are allowed to flourish and desires are multiplied that a framework of appropriate rules and norms can develop, in turn regulating behaviour. It does not work to suppress passions that motivate undesirable behaviour (De Marchi 2001). One may scare or flatter people into certain behaviours, but one cannot make them act virtuously by design. Even if it were possible to teach virtue it would hurt the public good given that both good and evil are ingredients of public benefits. In this sense he did argue for the necessity of vice. Instead of recommending vice, however, Mandeville claimed that passions and behaviour in all their moral variety enter into the development of sociability and morality. Consequently, one can only learn how interacting passions of individuals work out in practice, from experience and observation.

These ideas can directly be related to views Mandeville developed as a physician (Cook 1999; De Marchi 2001). In his medical writings Mandeville

\footnotetext{
${ }^{9}$ Weststeijn $(2012,353)$ acknowledges that Mandeville "was clearly indebted to the thought of the brothers De la Court" but only repeats Hundert's assessment of Mandeville's intentions as trying to debunk the De la Courts' republican dream (1994, 29).
} 
argued for the need to work with and learn from nature, contending that the proper task of the physician is to support nature in its attempts to cure a disease. Treatment should be based on experience and observation of the normal run of diseases, its natural symptoms, and the ways of nature towards restoration of health. The attending physician needs to build a case history and must be prepared to observe how a disease presents itself in a particular patient before any assistance can be given toward curing the disease. The role of the legislator is comparable to that of the physician. By accepting man's passions and fickle nature, rather than suppressing them, the legislator aims to redirect their course by changing the structure of incentives by way of rules and regulations, when interacting passions have undesirable outcomes.

In pursuing his interests and learning from his experiences (and assisted by the legislator), man spontaneously and tentatively stumbles upon arrangements through which he is induced to restrain his passions in his efforts to pursue his own interests. As unintended consequences of this process of discovery the arts and sciences, as well as trades and manufactures develop and are made to flourish, whereby man may be said to be useful to others. By way of these institutionalized forms of advancing self-interest, a hybrid morality is constituted. Taking pride in controlling their passions, human vanity deceives one into believing that they act as if they have the welfare of others in mind and thereby create advantages to the public good. This mechanism by which men come to practice virtue works in Mandeville's framework thanks to the mutual encouragement of the same passions and desires which earlier were condemned by moralists as excessive and disruptive to the health and wealth of society.

\section{CONCLUSION}

It is typical in the literature on Mandeville's philosophy to reference him as the Dutch doctor. I have argued that it was not only his being a doctor that is relevant. The relevance of his Dutch background, and especially the influence of the brothers De la Court, have been noted but never carefully analysed (cf., Hundert 1994; Cook 1999; Weststeijn 2012). As a result, Mandeville's work is too easily placed in the context of the French moral tradition, while the influence of Dutch authors is usually marginalized. Such an account misses out on a source that became an important springboard for his ideas: the Dutch commercial republicanism of the brothers De la Court. 
After all, Mandeville was raised in a republican environment, whose family was associated with members of the city council and merchants in Rotterdam, who also made up the States Party (Dekker 1992; Cook 2007). The States Party, led by Johan de Witt, had controlled the United Provinces after the death of William II in 1650, effectively establishing a republican form of government until 1672 whereby William III seized control of government. Mandeville's grandfather and father were in close contact with Adriaen Paets, a lawyer, city counsellor, and one of the leaders of the States Party in Rotterdam, who knew and corresponded with Pieter de la Court (Cook 1999, 117). In 1685 Mandeville matriculated at the University of Leiden to study philosophy and medicine in the hometown of the De la Courts. At the university "empiricism and biological materialism had a platform in medical Cartesianism" (Cook 1999, 117). Given his interest in Descartes's medical views, his bent for theorizing about society, and his republican background, it seems implausible that Mandeville not be influenced by the De la Courts Cartesian theory of the passions in devising political theory. Although there is no straightforward evidence, it is fair to assume that Mandeville was well-acquainted with the writings of the De la Courts.

And these writings did have something to offer. Indeed, the fact that Mandeville's thought is indebted to neo-Augustinian thought should not make us ignore obvious differences. First, although he agreed on the view that human actions are motivated by self-love, Mandeville did not deny the reality of virtue. The idea that fallen humanity is capable of doing moral good is not a delusion predicated upon pride. Second, in contrast to Augustinian moral doctrine, Mandeville's thought is not framed by theological premises but offers a naturalistic account of commercial society (Horne 1978; Jack 1975). Finally, for Mandeville virtue is a utilitarian notion, rather than an unattainable ideal of being good out of love for God.

All of these characteristics of Mandeville's philosophy may be found in the writings of the De la Courts, whose commercial republicanism was an attempt to understand and justify the profound changes in society; an attempt founded upon a positive theory of interest and the passions. Yes, man is driven by his selfish impulses, but with the right kind of self-love virtue is possible. Instead of defining society in opposition to virtue-i.e., as absolute, otherworldly, unattainablesociety follows a process of 'moral education', which develops naturally 
from man's selfish dispositions and political control. Pride, honour, praise, and shame are crucial elements for learning moral value. Civic virtue is within man's reach and originates in self-interest properly understood rather than some notion of the public good. The desire for wealth does not necessitate moral ruin but, properly managed and controlled, is the basis of true well-being or (self-) interest. In its positive sense then, interest is defined in terms of harmony between individual and collective well-being. As such, it contrasts sharply with the negative connotation of interest in neo-Augustinianism, taken in the sense of narrow self-love. This contrast reappears in the way both accounts view the desire for esteem and admiration. Whereas the one account takes vanity and pride as a restraining force that induces individuals to act virtuously, the other interprets the same passions as a vehicle of hypocrisy and vice. These two interpretations are joined together in Mandeville's notion of self-liking:

we are all born with a Passion manifestly distinct from Self-love; that, when it is moderate and well-regulated, excites in us the Love of Praise, and a desire to be applauded and thought well of by others, and stirs us up to good actions; but the same Passion, when it is excessive, or ill-turn'd, whatever it excites in our Selves, gives Offence to others, renders us odious, and is call'd Pride (Mandeville 1971, 6-7).

By integrating the positive and negative theories of passions and interest, Mandeville built a naturalistic account of the rise of society on the basis of the interaction of passions and institutions, exploring the mechanisms of praise, pride, and shame in shaping the sociability and morality of individuals within society. Thus Mandeville developed a new logic of (self-)interest, morality and society. Sharing the Augustinian belief that (fallen) man is driven by his selfish passions, Mandeville rejected the idea that passions undermine morality. Instead, he went along with the De la Courts by arguing for the moral potential of the passions, while dismissing their argument for the contractual basis of society, (through which, the brothers believed, rational control of the passions would be possible). Thus carving out what he took to be empirically sound, Mandeville argued that man was disciplined and socialized precisely because he is driven by passions and considerations of (private) gain. Removing the last traces of the elevated nature of virtue, he made the scandalous claim that moral virtue arises unintentionally out of efforts at gainful convenience. 
Mandeville went beyond the vision of the brothers De la Court by doing away with attempts to define self-love, interest, and welfare as dichotomously either false or true; such passions can only be evaluated against the backdrop of the form and conditions of government. One cannot reason from basic principles to arrive at some understanding of which passions to suppress and which to encourage. Understanding the passions required empirical observation and experience to build a case history of society, starting from (changing) circumstances and evolving social patterns and practices, thereby tracing and observing how passions work out in a process of socialisation and 'moral education'. Interested in this naturalistic process of moral education of man's passions, Mandeville inquired into the extent to which commercial modernity, with trade and commerce as the new basis of wealth and power, provided a context for virtue. In building such a new logic, he may be said to have presented an agenda for debate. Rejoicing in pointing out the discrepancies and contradictions in what was professed and what was done in practice, Mandeville framed his famous paradox. His rigorist notions of virtue and vice, as Kaye observed, "[i]s simply a final twist given to his thought after it has been worked out in harmony with the opposite or empiric viewpoint. It is a suit of clothes made for some one else which he has put on the living body of his thought" (Kaye 1988, liii). This twist, however, placed emphasis on (neo)Augustinianism at the expense of that other intellectual source of Mandeville's thought.

\section{REFERENCES}

Blom, H.W. 1995. Causality and morality in politics; the rise of naturalism in Dutch seventeenth-century political thought. Ridderkerk: Offsetdrukkerij Ridderprint.

Blom, H.W. and I.W. Wildenberg. 1986. Pieter de la Court in zijn tijd; aspecten van een veelzijdig publicist (1618-1685). Amsterdam: Holland University Press.

Brooke, Christopher. 2012. Philosophical pride: stoicism and political thought from Lipsius to Rousseau. Princeton: Princeton University Press.

Burke, Peter. 1981. Montaigne. Oxford: Oxford University Press.

Cook, Harold. 1999. Bernard Mandeville and the therapy of 'the clever politician'. Journal of the History of Ideas, 60 (1): 101-124.

Cook, Harold J. 2002. Body and passions: materialism and the early modern state. Osiris, 17: $25-48$.

Cook, Harold J. (2007). Matters of exchange: commerce, medicine, and science in the Dutch golden age. New Haven: Yale University Press.

Court, Johan de la and Pieter de la Court. 1662a. Consideratien van staat, ofte politike weeg-schaal. Ysselmonde: voor Querinus Overal.

Court, Johan de la and Pieter de la Court. 1662b. Politike discoursen. Leiden: Hackius. 
Court, Pieter de la. 1671. Aanwysing der heilsame en politike gronden en maximen van de republike van Holland en West-Vriesland. Leiden: Hakkius.

Court, Pieter de la. 1685. Sinryke fabulen. Amsterdam: Hieronymus Sweerts.

De Marchi, Neil. 2001. Exposure to strangers and superfluities Mandeville's regimen for great wealth and foreign treasure. In Physicians and political economy: six studies of the work of doctor-economists, ed. Peter Groenewegen. London: Routledge, 6792.

Ferguson, Adam. 1980 [1767]. An essay on the history of civil society. New Brunswick: Transaction Books.

Force, Pierre. 2003. Self-interest before Adam Smith: a genealogy of economic science. Cambridge: Cambridge University Press.

Frijhoff, Willem and Marijke Spies. 2004. 1650: hard-won unity. Basingstoke: Palgrave Macmillan.

Gilbert, Felix. 1965. Machiavelli and Guicciardini: politics and history in sixteenthcentury Florence. Princeton: Princeton University Press.

Horne, Thomas A. 1978. The social thought of Bernard Mandeville: virtue and commerce in early eighteenth-century England. New York: Columbia University Press.

Hundert, Edward J. 1994. The Enlightenment's fable: Bernard Mandeville and the discovery of society. Cambridge: Cambridge University Press.

Israel, Jonathan. 2004. Monarchy, orangism, and republicanism in the later Dutch golden age. Second golden age lecture. Amsterdams centrum voor de studie van de gouden eeuw.

Jack, M.R. 1975. Religion and ethics in Mandeville. In Mandeville studies: new explorations in the art and thought of Dr. Bernard Mandeville, ed. Irwin Primer. The Hague: Martinus Nijhoff, 34-42.

James, E.D. 1975. Faith, sincerity and morality: Mandeville and Bayle. In Mandeville studies: new explorations in the art and thought of Dr. Bernard Mandeville, ed. Irwin Primer. The Hague: Martinus Nijhoff, 43-65.

James, Susan. 1998. The passions in metaphysics and the theory of action. In The Cambridge history of seventeenth-century philosophy, ed. Daniel Garber and Michael Ayers. Cambridge: Cambridge University Press, vol. I: 913-949.

James, Susan. 2012. Reason, the passions, and the good life. In The Cambridge history of seventeenth-century philosophy, ed. Daniel Garber and Michael Ayers. Cambridge: Cambridge university press, vol. II: 1358-1396.

Kaye, F.B. 1988 [1924]. Introduction to Mandeville's Fable of the bees. Indianapolis: Liberty Classics.

Keohane, Nannerl O. 1980. Philosophy and the state in France. the Renaissance to the Enlightenment. Princeton: Princeton University Press.

Kossmann, E.H. 1960. Politieke theorie in het zeventiende-eeuwse Nederland. Verhandelingen der Koninklijke Nederlandse akademie van wetenschappen. Afdeling letterkunde. Nieuwe reeks, LXVII (2).

Lovejoy, Arthur O. 1961. Reflections on human nature. Baltimore: John Hopkins Press.

Mandeville, Bernard. 1953 [1732]. A letter to Dion, ed. Jacob Viner. Los Angeles: Clark Memorial Library. 
Mandeville, Bernard. 1971 [1732]. An enquiry into the origin of honour, and the usefulness of Christianity in war. Reprinted with an introduction by M.M. Goldsmith. London: J. Brotherton.

Mandeville, Bernard. 1988 [1724]. The fable of the bees or private vices, publick benefits, ed. F.B. Kaye, 2 vols. Indianapolis: Liberty Classics.

McKenzie, Lionel A. 1981. Natural right and the emergence of the idea of interest in early modern political thought: Francesco Guicciardini and Jean de Silhon. History of European Ideas, 2 (4): 277-298.

Montaigne, Michel de. 1957. Essays, Translated by D.M. Frame. New York: Hamish Hamilton.

Nicole, Pierre. 1696. Moral essays, contain'd in several treatises on many important duties, 4 vols. London: printed for Samuel Manship.

Nieuwstraten, Jaap. 2012. Historical and political thought in the seventeenth-century Dutch republic: the case of Marcus Zuerius Boxhorn (1612-1653). Haarlem: Nieuwstraten.

Pascal, Blaise. 1958 [1670]. Pascal's pensées. Introduction by Thomas S. Eliot. New York: E.P. Dutton \& Co.

Pincus, Steve. 1998. Neither Machiavellian moment nor possessive individualism: commercial society and the defenders of the English commonwealth. The American Historical Review, 103 (3): 705-736.

Pocock, John Grevilel Agard. 1975. The Machiavellian moment: Florentine political thought and the Atlantic republican tradition. New Jersey: Princeton.

Pocock, John Greville Agard. 1985. Virtue, commerce and history. Cambridge: Cambridge University Press.

Sedgwick, Alexander. 1977. Jansenism in the seventeenth-century France. Charlottesville (VA): University Press of Virginia.

Velthuysen, Lambert van. 2013 [1651]. A letter on the principles of justness and decency. Boston: Brill.

Verburg, Rudi. 2015. Bernard Mandeville's vision of the social utility of pride and greed. The European Journal of the History of Economic Thought, 22 (4): 662-691.

Viroli, Maurizio. 1992. From politics to reason of state: the acquisition and transformation of the language of politics 1250-1600. Cambridge: Cambridge University Press.

Weststeijn, Arthur. 2010. From the passion of self-love to the virtue of self-interest: the republican morals of the brothers De la Court. European Review of History: Revue européenne d'histoire, 17(1): 75-92.

Weststeijn, Arthur. 2012. Commercial republicanism in the Dutch golden age: the political thought of Johan \& Pieter de la Court. Leiden: Brill.

Wildenberg, Ivo W. 1986. Johan \& Pieter de la Court (1622-1660 \& 1618-1685) bibliografie en receptiegeschiedenis. Amsterdam: Holland University Press.

Rudi Verburg is assistant professor in the history of economics at the Erasmus University of Rotterdam, The Netherlands. His research interests include eighteenth-century economic thought, Adam Smith, institutional theory and ethics and economics. He is currently writing on the history of greed and self-interest in economics.

Contact e-mail: <verburg@eshcc.eur.nl> 